\title{
Az állam szerepe a „közterek hanyatlásában” - történelmi perspektívában
}

\section{The role of the state in the decline of public space - a historical perspective}

\section{SÁGI MIRJAM}

SÁGI Mirjam: PhD-hallgató, Eötvös Loránd Tudományegyetem, Társadalom- és Gazdaságföldrajzi Tanszék; 1117 Budapest, Pázmány Péter sétány 1/c.; mirjam.sagi@gmail.com; https://orcid.org/0000-0001-9819-5616

KULCSSZAVAK: köztér; militarizáció; Budapest; államszocializmus

ABSZTRAKT: A tanulmány a kritikai földrajz által koncepcionalizált városmilitarizáció következtében kialakult köztérhanyatlás jelenségét vizsgálja történeti perspektívában, kiemelve az állam szerepét, Magyarország és elsősorban Budapest kontextusában. A történetiség azért kapott itt fontos hangsúlyt, mert bár az angolszász irodalom által tárgyalt városmilitarizációs tendenciák jellemzik Budapest utcáit is, a köztér hanyatlásának elmélete azt feltételezi, hogy valaha létezett olyan köztér, ami korábban demokratikusabb volt.

A nemzetközi irodalom áttekintése során a köztér jelentésével, és a városmilitarizációval, a közterek hanyatlásával foglalkozom. Ezt követően a második fejezet első részében elsősorban magyar kontextusban vizsgálom az állam szerepét a köztér és a magántér vonatkozásában, majd a második és a harmadik alfejezetben a vonatkozó szakirodalom mellett Papp Gábor Zsigmond (1998) archív videófelvételeket tartalmazó összeállítását, a Budapest Retrót és a Budapest Főváros Tanácsa tanácsülési jegyzőkönyveit használom az elemzéshez. A tanulmány fö következtetése az, hogy a Davis által leírt város-militarizáció - amit a tőke és a piaci érdekeket kiszolgáló állam és a neoliberális városvezetés együttesen eredményez -, jelen van Budapesten is, és a 2000-es évektől egyre inkább jellemző. Azonban a történeti áttekintés azt mutatja, hogy Budapest esetében a köztér demokratikus jellege hiányának távolabbra visszanyúló helyi sajátossága is van, hiszen a gyökerei már az államszocializmusban is jelen voltak, olyan - a köztér használatát szükítő és abban bizonyos csoportokat privilegizáló - politikák formájában, melyek hátterében az állam állt.

Mirjam SÁGI: PhD student, Department of Social and Economic Geography, Eötvös Loránd University; Pázmány Péter sétány 1/c, H-1117 Budapest, Hungary; mirjam.sagi@gmail.com; https://orcid.org/0000-0001-9819-5616

KEYWORDS: public space; militarisation; Budapest; state socialism

ABSTRACT: According to Mike Davis, the militarisation of urban space is a process that builds a city around securitisation, leading to an urban space made exclusive through surveillance and disciplining strategies. The end or decline of public space is described as the result of such militarisation processes by critical theorists who linked it to capitalist, neoliberal city governance. Thus understood, urban space is formed by capital to achieve an economically more competitive city, leading to the displacement of the poor and homeless. As a result, public space ceases to exist as the epitome of democracy, as a place where different social groups can mingle and voice their discontent.

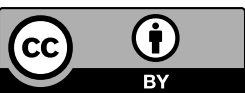


While such processes of militarisation increasingly characterise the urban spaces of Budapest, too, it is not necessarily the case that the discourse on the "decline" or "end of public space" also applies to Budapest when it is analysed from a local and historical perspective. In addition, the question arises as to whether there has ever actually been a more democratic public space in Budapest.

This article focuses on the changing role of the state through its interpretation of the meaning and use of public space, starting from Lefebvre's argument that power is mediated through space. In addition to Lefebvre's theories on the production of space, this study is informed by Susan Gal's paper on the semiotics of public/private distinction, as it is helpful for a deeper understanding of the relationship between the state and public space. Based on feminist theory, Gal argues that the difference between public and private is ideologically defined. Therefore, the relation between public and private cannot alone describe society, it rather acts as a tool for argument or discussion of value systems.

The aim is to understand from a historical perspective the decline of public space and the militarisation of urban space as discussed by critical theorists in the case of Budapest. For such urban tendencies should be seen not only with regard to capital(ism) but also in the context of (central and local) governments. The basis is provided by analyses of both the minutes of the Budapest Metropolitan Council of 1978 and archive footage (news and advertisements) from the 1960 s to the 1970 s.

The article concludes that although the militarisation of urban space described by Davis also characterises Budapest, especially since the 2000s, the author's historical research suggests that in the case of Budapest the lack of democratic public space has a longer history than neoliberal urban planning, rooted in the period of state socialism when other policies of exclusion privileged certain social groups.

\section{Bevezetés}

A városi tér militarizációján Davis $(1999-2000,2006)$ azokat a folyamatokat, városkormányzási stratégiákat érti, amelyeknek központi eleme a város rendjének és biztonságának megfigyeléseken és szabályozásokon alapuló elősegítése. A kritikai elmélet e politikát a kapitalista, neoliberális városvezetésnek tulajdonítja, és a (demokratikus) közterek hanyatlását ezeknek a militarizációs folyamatoknak következményeként írja le (Davis 1999-2000, 2006; Harvey 2012). Ebben az értelmezésben a városi teret a tőke formálja egy gazdaságilag versenyképesebb városi tér létrehozásának érdekében, ami a szegényebb rétegek, elsősorban a hajléktalanok kiszorításához vezet. Így a köztér megszűnik a demokrácia megtestesítőjeként létezni, ahol különböző társadalmi csoportok találkozhatnának vagy szükség esetén hangot adhatnának elégedetlenségüknek.

Míg az említett militarizációs folyamatok jellemzik napjaink Budapestjét is, a köztér nyugati értelemben vett „hanyatlása” történeti és helyi perspektívába helyezve korántsem biztos, hogy pontosan írja le ezeket a változásokat. Sőt, felveti a kérdést, hogy létezett-e korábban demokratikus(abb) köztér Budapesten?

Jelen cikkben az állam változó szerepét a köztereinek értelmezésén, használatán keresztül vizsgálom. Ebben Lefebvre elmélete segít, miszerint a (társadalmi) tér a hatalom egyik fö közvetítője (Lefebvre 1991; Timár, Nagy 2019). Az állam és a közterek viszonyának mélyebb megértéséhez - Lefebvre tértermeléssel foglal- 
kozó elméletei mellett - nagy segítséget nyújt Susan Gal (2002) írása, amely a nyilvános és privát közti szemiotikai különbségeket vizsgálja. Gal (2002) a feminista irodalmat követve amellett érvel, hogy a nyilvános és a privát közti különbség ideológiailag meghatározott. Tehát a nyilvános és a privát közti viszony önmagában nem írja le a társadalmat, hanem sokkal inkább érvek, érvrendszerek eszközeiként funkcionál.

A célom az, hogy a demokratikus közterek hanyatlását és a városi tér militarizációját - elsősorban angolszász kritikai irodalom tanulságainak alapján - Budapest kontextusában, történeti perspektívában vizsgáljam. Arra szeretnék rámutatni, hogy a jelenlegi, militarizáló várospolitikát nem csak a nyugati, neoliberális tendenciák fényében érdemes kutatni. A központi, illetve helyi állam szerepének megértéséhez magyarországi viszonylatban fontos adalékokat szolgáltathat az államszocializmus időszakának tanulmányozása. Mivel a cikk fókuszában az államszocialista időszak áll, nem volt célom, hogy az államszocialista időszakot az azt követővel szisztematikusan hasonlítsam össze. Tágabb értelemben tehát a cikk néhány példán keresztül arról gondolkozik, hogy miként formálja a történelmi perspektíva a helyi, köztérről alkotott képünket, és mennyire torzítja a lokális értelmezést a nemzetközi diskurzus: jelen esetben a közterek hanyatlásáról szóló vita kapcsán.

Ennek megfelelően két nagyobb részre osztottam a tanulmányt, melyben előszőr a nemzetközi irodalom feldolgozásával, majd annak magyarországi, budapesti vonatkozásával foglalkozom. A második fejezet első részében elsősorban magyar összefüggésben vizsgálom az állam szerepét a köztér és a magántér vonatkozásában, majd a második és a harmadik alfejezetben a vonatkozó szakirodalom mellett Papp Gábor Zsigmond archív felvételeket tartalmazó összeállítását, a Budapest Retro címü filmet, valamint a Budapest Főváros Tanácsa tanácsülési jegyzőkönyveinek egyikét használom az elemzéshez.

\section{Közterek hanyatlása és az állam a nemzetközi tudományos diskurzusokban}

A város köztereinek tanulmányozása jó eszköz a város társadalmi rendszerének megértéséhez. A köztér megjeleníti használóinak a társadalmi, gazdasági és politikai helyzetét. Nemcsak azt figyelhetjük meg, hogy a városi vezetés (ill. az állam, a globális viszonyok) hogyan alakítják a várost, de azt is, hogyan alakulnak a hatalmi viszonyok: mennyi beleszólása van a város lakóinak a közterek alakításába, és mely társadalmi csoportok érdekei dominálnak a köztér formálásában (Czirfusz et al. 2018; Sági 2018). Nem véletlen tehát, hogy a közteret (public space) és közszférát (public sphere) sokszor szinte felcserélhető módon használja a szakirodalom. Ehhez kapcsolódik a nyugati marxista irodalomban fellelhető azon elképzelés is, miszerint a kapitalizmus hatásainak következtében a demokrácia, 
mint a nyugati társadalmakat évtizedek óta meghatározó társadalmi-politikai rendszer (azaz közszféra), a hanyatlásával a fizikai közterek hanyatlásához is vezet. Ahogy azt néhányan hangsúlyozzák, a köztér nem univerzális tartalmú, statikus fogalom, hanem térben és időben is folyamatosan változik a jelentéstartalma (Bodnár, Molnár 2010; Mitchell 2003). Nem elhanyagolható tehát a közterek tanulmányozása során a történeti, földrajzi kontextus ahhoz, hogy a köztér militarizációjáról vagy hanyatlásáról beszélhessünk. Ebben a fejezetben a köztér definíciójával, majd annak (vélt) hanyatlásával foglalkozom.

\section{A köztér értelmezése}

Annak érdekében, hogy a közteret a jelen tematikában (hanyatlás történeti elemzése) tárgyalhassuk, érdemes két (de egymástól nem elválasztható) irányból megközelíteni annak definícióját, részben Habermasnak (1991) a „társadalmi nyilvánosság szerkezetváltozásáról” írt könyvére támaszkodva. Az egyik megközelítésben a közszféra és a fizikai köztér viszonyát, a másik megközelítésben pedig a magán- és a köztér kapcsolatát hangsúlyozza. Mindkét megközelítésnek megvan a maga relevanciája: míg az előbbi a demokratikus berendezkedést mint a köztér feltételét tárgyalja (így tehát központi kérdéseket vet fel pl. az államszocialista köztér kapcsán), a második nézőpont a magán- és a köztér (vagy -szféra) kapcsolatának korántsem egyértelmű viszonyára mutat rá, amelynek segítségével az állam változó szerepét vizsgálhatjuk meg.

Habermas (1991) társadalomtörténeti elemzésében arról olvashatunk, hogy a 18-19. században megjelenik a közszféra (ill. a nyilvánosság) egy újabb formája, a nyilvános viták és a hozzájuk kötődő terek (például kávéházak) elterjedésével, magával hozva egy kritikusabb hangot a tradicionális autoritásokkal szemben. Azonban, ahogy azt Habermas is megjegyezte, a közszférának ez a formája korántsem volt ideális, hiszen alapvetően burzsoá volt és ennek megfelelően képtelen a társadalom valamennyi tagjának a képviseletére. Ugyanakkor ezek a politikai, társadalmi viták kezdetleges modellként szolgáltak arra, hogyan is müködhet a nyilvános diskurzus (,publicity”).

Habermas szerint ezt a modellt azonban, kiteljesedése elött, ellehetetlenítette a korai kapitalizmus, mivel lényegében kisajátította, instrumentalizálta és ezáltal depolitizálta ezeket a tereket, középpontba helyezve a fogyasztást. Ezek a gondolatok alapozták meg azokat a neomarxista elméleteket, amelyek a városhoz való jogot mint alapvető emberi jogot határozzák meg. Henri Lefebvre (1996) értelmezésében a köztér jogi definíciója önmagában meghatározza, hogy egy város és annak társadalma mennyire tudja képviselni és befogadni a különböző társadalmi csoportokat. A fentiekből kiindulva, ahogy Lefebvre (1967/1996) is írja, a demokráciában való részvétel, illetve a városhoz való jog, a tőke által meghatározott érdekek hatására háttérbe szorul, ami többek között a városi terek privatizációjában nyilvánul meg, bizonyos tereket teljesen vagy feltételesen elzárva 
lakóitól. Ez mind fizikailag, mind törvényileg, mind pedig szimbolikusan korlátozza az explicit vagy implicit politikai megnyilvánulásokat. Ezzel az érvelésével Lefebvre megalapozta azt a későbbi álláspontot, miszerint napjainkban (illetve az elmúlt 20-25 évben) a közterek hanyatlásával szembesülünk. Ezt bővebben a következő fejezetben fogom kifejteni.

Az előző gondolatmenet elvezet a második megközelítéshez, amely a magánés a közszféra viszonyát helyezi a középpontba. Ebben a megközelítésben a nyilvánost (illetve a közszférát, közteret) az ellentétpárja határozza meg, tehát leegyszerüsítve: ami nem magántér, az köztér. Ennek a dichotómiának a kritikáján alapszik a feminista (város-)földrajzi megközelítés, miszerint a magánszféra és a privátszféra drasztikus elkülönülése felerősíti a hagyományos nemi szerepeket, mivel a nők lakóterekhez kötöttsége megnehezíti a nők számára a „maszkulin" (bel)városi térben való mindennapi jelenlétet (Saegart 1981; Sági 2018; Timár 1993, 2018). Nem meglepő, hogy ezek az elméletek az 1980-as évek amerikai szuburbanizációs folyamatai kapcsán kezdtek elterjedni, melyekből kiindulva a feminista városkutatók azt állították, hogy a kapitalizmus következtében a termelés és a reprodukció terei elkülönültek (McDowell 1983; Saegart 1981). Későbbi írások azonban jelentős kritikával illették ezt a markáns elkülönítést, mondván: ez az életvitel csak a középosztálybeli nemi viszonyokat jellemzi (Timár 2018; Wilson 1995). A feminista felvetésekkel gyakran szorosan összekapcsolódva, a városi teret kutató marxista tanulmányokban is fontos szerepet kap a magán- és a köztér viszonyának tárgyalása. Ez a megközelítés azonban a tőke eloszlását helyezi központi szerepbe, és arra fókuszál, hogy bizonyos (városi) terek, területek magánvagy köztulajdonban vannak-e, illetve, hogy mely csoportok érdekeit, kényelmét szolgálják, és hogy mennyire határozzák meg a teret a tőke által definiált érdekek. A tulajdonrendszer vizsgálata tehát önmagában nem nyújt kielégítő analitikai keretet. Ahogy az a jogi definíciókból és a tudományos diskurzusokból is kiderül, a hozzáférhetőség / látogathatóság legalább annyira meghatározó. Ezek alapján a következő négy általánosabb kategóriát különítettem el: Az első kategóriába tartozik az a köztér, amely köztulajdonban (központi állami / önkormányzati tulajdonban) van, a fenntartója is állami vagy önkormányzati szerv, és mindenki számára hozzáférhető. A következő kategóriába azok a területek tartoznak, amelyek ugyan köztulajdonban vannak, de privát fenntartójuk van. A harmadik kategória, a „kvázi” köztér, amely magántulajdonban van, de alapvetően mindenki azonos (de a tulajdonos által meghatározott) feltételek mellett használhatja. Megemlíthetők továbbá a köztulajdonú, de korlátozott hozzáférésü területek, mint például a parlament, minisztériumok, múzeumok vagy egyéb állami intézmények, amelyek csak korlátozottan látogathatók. Lefebvre (1996) (és őt követve a kritikai geográfusok) a tulajdonviszonyt és a hozzáférhetőséget kiegészítették a kisajátíthatóság, birtokbavétel (appropriation) lehetőségével, azaz, hogy a köztér akkor lesz igazán köztér, ha nemcsak szabadon látogatható mindenki számára, de mindenkinek egyformán van lehetősége alakítani, illetve visszavezetve az előző megközelítés- 
hez, ott (arról) politikai véleményt nyilvánítani, megmozdulásokat szervezni. Ebben az írásban ezt, a Lefebvre által is meghatározott köztér definíciót tartom irányadónak.

A fentiek alapján elmondható, hogy mind a demokrácia és a köztér, mind a magán- és a köztér viszonya olyan változó és ambivalens kapcsolatok, amelyek segítenek megérteni a tágabb értelemben vett társadalmi berendezkedéseket és azok változásait, illetve a jelen tanulmányban a köztér hanyatlásának és a város militarizációjának relevanciáját Budapesten.

\section{A köztér militarizációja és hanyatlása}

Mindezek alapján tehát a (városi) köztereket egyre nagyobb mértékben határozták és határozzák meg a fogyasztás, illetve a fogyasztóképes társadalom igényei (mint a magán- és állami befektetők elsődleges célközönségei). A fogyasztók számára vonzó városi tér azonban komplex erőfeszítések eredménye. Olyan erőfeszítések, amelyekhez különböző stratégiákra és technológiákra van szükség (Davis 1992, 1998/2006). Ide tartoznak például a biztonságot (vagy esetleg biztonságérzetet) nyújtó térfigyelő kamerák, a rendőri vagy magáncégek által biztosított felügyelet, illetve általában a megtisztított, vonzó külsejü köztér. Ez azonban a köztérnek a politikában betöltött, demokráciát erősítő szerepét veszélyezteti, hiszen alapból kirekeszti a fogyasztásképtelen rétegeket, leszűkíti és szabályozza a megengedett viselkedési normákat, mintegy megfigyelés alatt tartja a térhasználókat (Bancroft 2000).

Foucault (1991) metaforája a panoptikum típusú börtönökhöz hasonlítja ezt a megfigyelés alatt tartott teret, ahol az elmélet szerint az állandó megfigyeltség tudata önmagában biztosítja a rendet. Davis (1999-2000) hasonlóan érvelt a Los Angeles, az erődváros: a városi tér militarizációja című írásában, kiemelve az épített környezet meghatározó szerepét, amire az 1980-1990-es évek Amerikájában elszaporodó bevásárlóközpontokat hozza fel példának, melyek ugyancsak a panoptikum elvén alapulnak.

Két évtizeddel később Madden (2010) arról ír, hogy a különböző autoritások felülről jövő megfigyelési stratégiáit felerősítik a társadalmi elvárások. Ezt pedig Bauman (2000) szinoptikum (synopticon) modelljének segítségével írja le, amit a fent említett foucault-i fogalomra épít. Míg Foucault panoptikusság-koncepciójában a megfigyeltségtől való félelmet különböző autoritások generálják, addig Bauman szinoptikumjában a társadalmi elvárások generálják ezt a szorongást. Bauman (1998) ennek kapcsán definiálja a fogyasztói társadalom kirekesztettjeit, akik „alkalmatlan fogyasztóként” (flawed consumers), kulturális és/vagy gazdasági tőke hiányában, nem képesek „megfelelő” fogyasztóként a közösség részesei lenni.

Ahogy Iveson (2007) is írja, a helyzetet komplikálja, hogy mások szerint viszont éppen a fent említett, kirekesztőként jellemzett biztonsági intézkedések és morális kontrollok teszik sokak számára elérhetővé a köztereket. Ez alapján a 
„rendes polgárok” számára a rendezett és biztonságos köztér biztosításához olyan intézkedésekre van szükség, amelyek megóvják a járókelőket attól, hogy „kéregetők félemlítsék meg, graffitik vagy kamaszok csoportjai fenyegessék őket, megóvják a hajléktalanok látványától vagy attól, hogy húgy szag terjengjen" (Iveson 2007 , 6.). Iveson hangsúlyozza azonban, hogy ezek már mind csak a tünetei egy adott társadalmi berendezkedésnek. Hubbard (2001) határozottabban érvel a kritikusan kizárólagos terek mellett a radikálisan befogadó terekkel szemben, mondván, az ilyen, védelmet biztosító terek alkalmasak csak arra, hogy kompenzálják azokat a hátrányokat, amelyeket különböző (marginalizált) társadalmi csoportok (pl. idősek, nők, vallási kisebbségek, melegek, mozgássérültek) tapasztalnak a domináns társadalmi csoportok számára kényelmessé tett tereken. Míg nyugat-európai kontextusban már egyre több olyan kritikusan kizárólagos teret találunk, amely valóban egyes marginalizált csoportoknak hivatott a városi térhez való jogát biztosítani, többségében azonban a kizárólagosság továbbra is a domináns csoportok érdekeit védi, illetve fennáll a kérdés, hogy hosszútávon segítik-e a társadalmi integrációt (Sági 2018).

Mindenesetre, ahogy Madden (2010) és Atkinson (2003) is írja, nem minden biztonsági intézkedés káros, és vélhetően megoldható, hogy a biztonság és a sokszínűség megférjen egymás mellett, és nem kell, hogy a köztereket vagy a piac által diktált fogyasztás, vagy a bünözés határozza meg (Madden 2010).

Összefoglalva tehát fontos, hogy a nyugati kritikai irodalom, amikor a „túlellenőrzött” városokról ír, akkor nem a városi terek „farkastörvényei” mellett érvel, hanem a tőke dominánsan meghatározó, térformáló szerepét kritizálja, amely a fogyasztókat és a fogyasztást, illetve a fogyasztói társadalom által meghatározott viselkedési normákat helyezi előtérbe, részesíti előnyben.

\section{Az állam szerepe a közterek változásában Magyarországon}

A fent említett tendenciák többé-kevésbé jellemzik Budapest, illetve Magyarország köztereit is: egyre gyakoribbak, és az utóbbi 5-10 évben különösen felerősödtek a hajléktalanokat kriminalizáló intézkedések ${ }^{1}$, elterjedtek a térfigyelő kamerák ${ }^{2}$ és megszaporodtak a privát cégek biztonsági őrei ${ }^{3}$ is (Ivanics 2013; Misetics 2010, 2017; Sági 2016; Udvarhelyi 2014, 2019). Azonban érdemes kitérni azokra a kérdésekre, amelyek itt más jelentést adhatnak a köztérnek, illetve a köztér militarizációjának. Ezek új szempontokkal szolgálnak az állam változó szerepének megértéséhez az 1950-es évektől napjainkig. A következő fejezetekben a nyilvános és a privát tér viszonyának alakulását, majd a közterek körül kialakult állami diskurzusokat vizsgálom archív, hivatalos állami dokumentumok és állami médiában megjelenő diskurzusok segítségével. A hosszú időszakot felölelő történeti áttekintésnek a célja a különböző tendenciák bemutatása Budapest esetében. Ehhez egyrészről a Budapest Főváros 
Tanácsa tanácsülési jegyzőkönyveinek egyikét, másrészről pedig Papp Gábor Zsigmond (1998) kizárólag archív filmfelvételeket tartalmazó összeállításának, a Budapest Retro-nak a részleteit használom. A Budapest Retro egy 1960-1970-es évek reklámfilmjeiből, és híradórészleteiből készült összeállítás, ami öt fejezetből áll (a pesti utca; a pesti lakás; a pesti bisztró; a pesti divat; a pesti autó). Ebben az írásban a tematikus válogatás „Budapest utcái” című fejezetét emelem ki. A film leírása szerint, az összeállításban

„nem a fóvárossal kapcsolatos történelmi és politikai eseményeké a fószerep, még csak nem is az építészeti arculatváltásokat követik nyomon. Sokkal inkább a „város lelkét" kívánják megragadni és feltárni. Azt, hogy miként éltek a fóvárosiak a hatvanas, hetvenes években."

A jegyzőkönyvek közül pedig itt elsősorban egy 1978-as jegyzőkönyvet emelek ki. Egyrészről azért ezt a jegyzőkönyvet, mert a HUNGARICANA ${ }^{4}$ online felületén végzett kulcsszavas keresés alapján az derült ki, hogy ez az első nagyobb léptékü, közterekkel foglalkozó hivatalos dokumentum (ahol a köztér nem kizárólag helymegjelölésként vagy emlékmüállítás, utcatábla csere kapcsán jelenik meg) ${ }^{5}$. Másrészről pedig a dokumentum szimbolikus fontossága miatt: A Budapest Főváros Tanácsának 1978-as tanácsülési jegyzőkönyve meghatározó dokumentum volt a későbbiekre nézve is, mivel „A főváros rendje és tisztasága" címu” fejezet alapozta meg a ma is müködő Budapest Főváros Közterület-felügyelet alapelveit, illetve ez a dokumentum vezetett annak 1983-as megalakulásához is. ${ }^{6}$

\section{„A magánügy közügy" - az állam hatása a magán- és a köztér viszonyára}

A nyilvános és a privát terek közti különbségek és a kettő között húzódó határvonalak kérdése nemcsak a 19. századi gondolkodóknak, tudósoknak volt egyik központi témája. A szovjet és a kelet-közép-európai országok kommunista pártjai is alapvető társadalomtervezési (social engeering) eszköznek tekintették ezt a térrendezési technikát a burzsoá, kapitalista társadalmak átalakításának céljából (Gal 2002). Ennek az egyik legalapvetőbb formája a privátszféra megszüntetése volt, illetve az állami kontrol „privát” térbe és tevékenységekbe való kiterjesztése, aminek ideológiai alapot az egyenlőtlenségek megszüntetésének elve adott, többek között a nők elnyomásával szemben való fellépés érdekében, a nők privát és a férfiak nyilvános térre korlátozásával szemben (Gal 2002). Az egyes államszocialista országok között és a különböző történeti időszakokban jelentős különbségek jellemezték a társadalomszervezés formáit. Magyarország esetében 1956-nak különös jelentősége volt ilyen szempontból is, hiszen ahogy Gal (2002) is írja, a rendszer enyhülésének következtében az állam kevésbé ellenőrizte a munkán kívüli tevékenységeket.

Az alcímben használt („,a magánügy közügy”) jelszó mindenesetre szemléletesen ábrázolja a magán- és a közügy egyáltalán nem egyértelmű viszonyát, továbbá, hogy miként élik meg különböző társadalmak a kettő elválasztását vagy 
éppen összeolvadását. Jelen esetben kifejezi a „két tér közötti fal elvékonyodását” a rendszerváltozás előtti időkben, ahogy Reszler is írja:

„A hatalom folyamatosan szem előtt kívánta tartani alattvalóit, ezért a munkahelyen, köztereken, sőt még az otthoni életkeretekben is figyelemmel kísérte őket. Ezen utóbbi megfigyelői szerepkört többek között a városok lakótömbjeiben a házfelügyelők, házbizalmik látták el. A totalitárius hatalom fürkésző tekintetei voltak ők, akik lesték, ki kivel találkozik, kihallgatták, ki hogyan vélekedik politikai kérdésekről" (Reszler 2014, 237).

A magán és a nyilvános közötti határvonal zavarosságát csak felerősítette az a tulajdonviszony-rendszer, amelyben tulajdonképpen minden tér köztulajdonnak volt mondható. Az állam szigorú felügyelete alatt álló területeken a hatalom határozta meg a társadalmi szerveződések szinte minden formáját (Tyshchenko 2014). Ebben az értelemben tehát ezek a terek inkább voltak „közösségi” terek, mint közterek, és a politikai jellegű események is felülről szerveződtek. A köztereken a hatalom által szervezett ünnepségek, felvonulások, tömegdemonstrációk sora zajlott, a nyilvános teret szinte kizárólagosan csak az államilag szervezett tömegrendezvényekre lehetett igénybe venni. „Ezeknek az eseményeknek a térhasználata tükrözte a hatalom természetét: az emelvényen, tribünön a vezetők, a felvonulási téren a tömeg" (Reszler 2014, 238.; Tyshchenko 2014).

Az állam által politikailag meghatározott közterekkel szemben részben a magánszféra lett az a terület, ahol a központilag meghatározott ideológiától eltérő gondolatokat lehetett megfogalmazni, és ezáltal bizonyos szempontból a magántér a köztér szerepét is betöltötte. Gal (2002) úgy írja le ezt a jelenséget, hogy a magánszféra gyakorlatilag két részre oszlott: egyrészről a reprodukcióra és a családra fókuszáló, hagyományos értelemben vett magánszférára, másrészről pedig a magánszférába beleágyazott nyilvános szférára. Ez a rejtett nyilvános tér tulajdonképpen két fó tevékenységet fedett le. A hivatalos munka mellett folytatott egyéb termelési folyamatokat (maszekolás), amelyek az 1980-as évekre az országos termelés 30 százalékát tehették ki nagyjából (részben az állam támogatásával), illetve a már fent említett privátszférába húzódó politikai tevékenységeket (szemben az állam politikájával).

Azonban az állam „füle” a házfelügyelőkön, családtagokon, barátokon keresztül beférkőzött ezekbe a terekbe is, még zavarosabbá téve, nemcsak a magánés a köztér vagy a magán- és a közügy határát, de a különböző emberi kapcsolatok, tevékenységek személyes, illetve publikus terekhez köthetőségét is. Egyes államszocialista országokban más-más mértékben. Ezen a ponton fontos visszacsatolni az alfejezet felütéséhez és hangsúlyozni, hogy ezeknek a határoknak, falaknak az elvékonyodása, definiálhatatlansága nem feltétlenül csak az autoriter hatalmak számára ideális. Erre példa, amikor a határok közti elvékonyodás nem kizárólag a hatalom fenntartását szolgálja, illetve a hatalom számára teszi az ellenőrzést és megfigyelést lehetővé (pl. családon belüli erőszak ellen való fellépés érdekében a demokratikusabb állam is ellenőrzi a privát szférát). 
A hatalom kontrollja alól fellélegzést jelentettek azok a mikroterek (Gyáni 2007), amelyeket mai értelmezés szerint kvázi-nyilvános térként vagy időszakosan köztérfunkciójú terekként definiálhatunk. Idetartoznak például az olyan alternatív szórakozóhelyek, mint az államszocialista időszak vége fele megnyitott, VIII. kerületi Fekete Lyuk. Illetve idetartoznak a magánlakásokban tartott politikai töltetű események, közös tanulások is, amik a hatalmat bírálták. Azonban fontos tudni, hogy ezek a helyek/események nem kerülték el a hatalom figyelmét, hanem a hatalom - a saját korlátait felismerve - engedélyezte müködésüket. (Így, a többségi társadalomtól elzártan, a hatalmat még nem veszélyeztető mértékben, kontrolláltanul vannak jelen.)

\section{$A z$ állami ideológia direkt és indirekt megnyilvánulása a köztereken}

Az elmúlt 70-80 évet áttekintve, az állam és az önkormányzatok köztereket érintő diskurzusait, intézkedéseit két nagyobb csoportra osztva vizsgálom. Egyrészről, úgy tekintek a közterekre, mint a hatalmi ideológia direkt kommunikálásának színtereire (pl. szobrok, emlékművek, politikai beszédek, utcanevek, felvonulások), másrészt mint a hatalmi ideológia közvetett megnyilvánulására, ami sokszor technokrata intézkedések mögé bújtatott (pl. rendészeti, turisztikai célú) térrendezési stratégia. Rövid kitekintést leszámítva, most elsősorban az utóbbival foglalkozom.

Az államszocialista időszak köztereit meghatározták a hatalomra és annak ideológiájára emlékeztető monumentális szobrok, utcanevek, és fontos szerepet játszottak a rendszer fenntartásában, majd később a lebontásában, a rendszer szimbolikus leépítésében és az új politikai diskurzus kialakításában. Magyarországon minden jelentősebb politikai rendszerváltozással a város-szöveget (citytext) újraírják: a hitelét vesztett (történelmi) alakok épített tájból való törlésével és az új „hivatalos történelem” szimbolikus kiépítésével (Palonen 2008; Erőss 2018). A mindenkori hatalom számára tehát fontos eszköz a városi tér ellenőrzése azért, hogy a saját „elképzelt közösségét” (Anderson 1983) egy saját szimbólumrendszeren keresztül a fizikai térbe is belevésse (Palonen 2008). A tanácsülési jegyzőkönyvekben található költségvetési tervekben is megjelenik az emlékmüvek fontos szerepe. Az egyik 1952-es Budapest Főváros Tanácsa tanácsülési jegyzőkönyvben például azt láthatjuk, hogy míg a tisztasági mozgalom ${ }^{8}$ tervezett költségvetése $520000^{9}$ forint, addig az Emlékmüfelügyelőség számára $2879000^{10}$ forintot tervez elkülöníteni a Főváros.

Míg a jegyzőkönyvek alapján nem lehet kijelenteni, hogy az emlékművek és a tisztaság relációja változott volna, és a direkt ideológiai megnyilvánulásokat leváltották volna a technokrata köntösbe öltöztetett indirekt ideológiai indoktrinációk, az egyértelműen kiderül, hogy egyre jelentősebb szerephez jut a rend és a tisztaság, amit legjobban az 1978. februári jegyzőkönyv fémjelez „A főváros rendje és tisztasága" című fejezetével. A fejezet, addig példátlan alapossággal tárgyalja Budapest rendjének és a tisztaságának kérdését. 
Feltűnő összhangot lehet felfedezni Papp Gábor Zsigmond 1998-as, archív felvételekből összeállított dokumentumfilmjének, a Budapest Retró-nak a „Budapest utcái" című fejezete és az 1978-as Budapest Főváros Tanácsa tanácsülési jegyzőkönyvének „A föváros rendje és tisztasága” része között. Ez utóbbi a VI. ötéves terv összeállítására készülve gyüjtötte össze a tennivalókat, a filmrészletek szereplői pedig néhol oktató jellegűen, néhol elismerően méltatják Budapest fejlődését ezen a területen. A szemetelés központi témaként szerepel, és antiszociális viselkedési formaként van feltüntetve, amin a tanácsülés szerint különböző oktatófilmekkel és kiadványokkal lehet javítani: „Növelni kell az emberi magatartás formálása érdekében a különböző kiadványok, kis-filmek stb. számát."11 Papp filmösszeállításában már egy 1960-ban készült televízióműsorban találkozhatunk ilyen típusú, oktató jellegü összeállítással, amiben a műsorvezető Ambrus Jánossal, a Fővárosi Tanács elnökével beszélget, aki először arról számol be, hogy rengeteget fejlődött a város tisztaság terén egy év alatt, amiért köszönetet mond a Fővárosi Tanács Végrehajtó Bizottságának és a város lakosságának is. Továbbá a rendőrökkel készített interjú mellett, amiben az interjúalany a büntetés eszközét hangsúlyozza, megjelenik a társadalmi nyomás fontossága is: „Ma már nem ritka látvány, hogy az utca egyszerű embere inti rendre a magáról megfeledkezőt, és ha arra szükség van, a közhangulat erejével kényszerítik a szemetelőt a jobb belátásra." (Budapest Retro 1998, 9:30.).

1. ábra: Polgárok egy csoportja egy fiatal férfit a szemét felvételére inti: „Minden fáradozás ellenére vannak még, akik nem méltóak arra, hogy városunk lakói legyenek” (Budapest Retro 9:30.)

A group of people telling off a young man for littering: „Despite all the troubles, there are still people who are not worthy of being a resident of our city." (Budapest Retro 9:30)

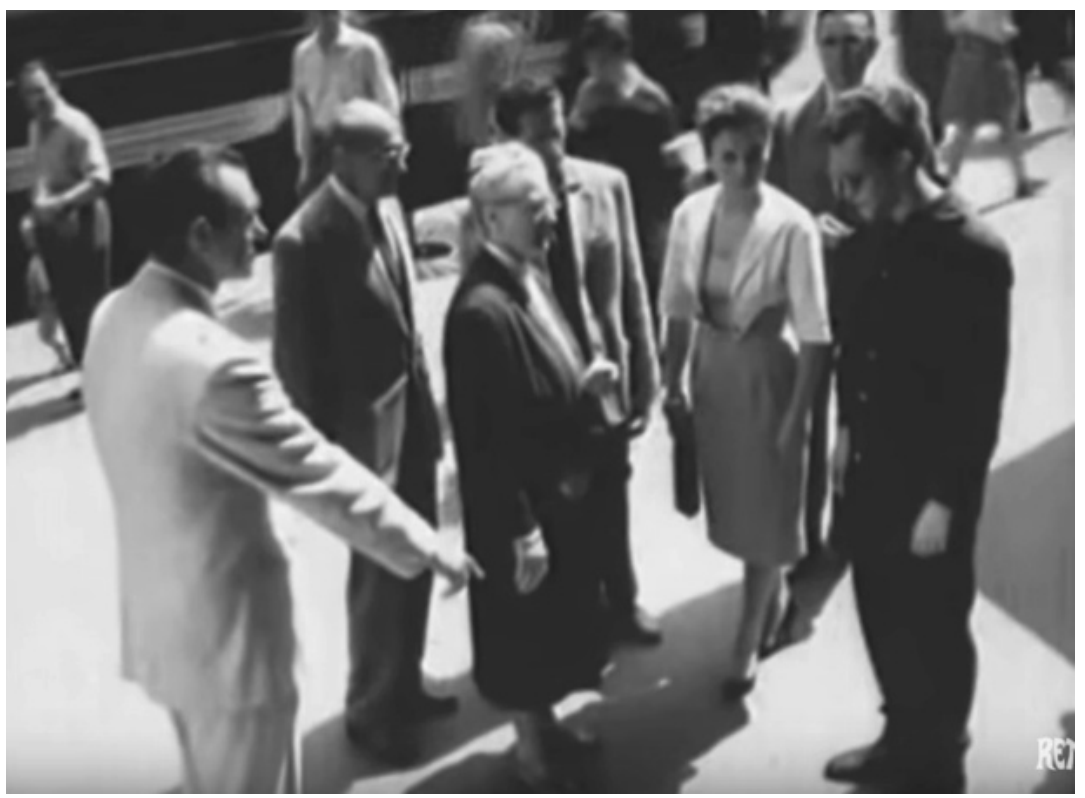


2. ábra: Turisták útbaigazítása: „A legtöbb pesti ember minden nyelven tud mutogatni.”

(Budapest Retro 14:05)

Giving directions to tourists: "There is not a single language a Pestian couldn't mime".

(Budapest Retro 14:05)

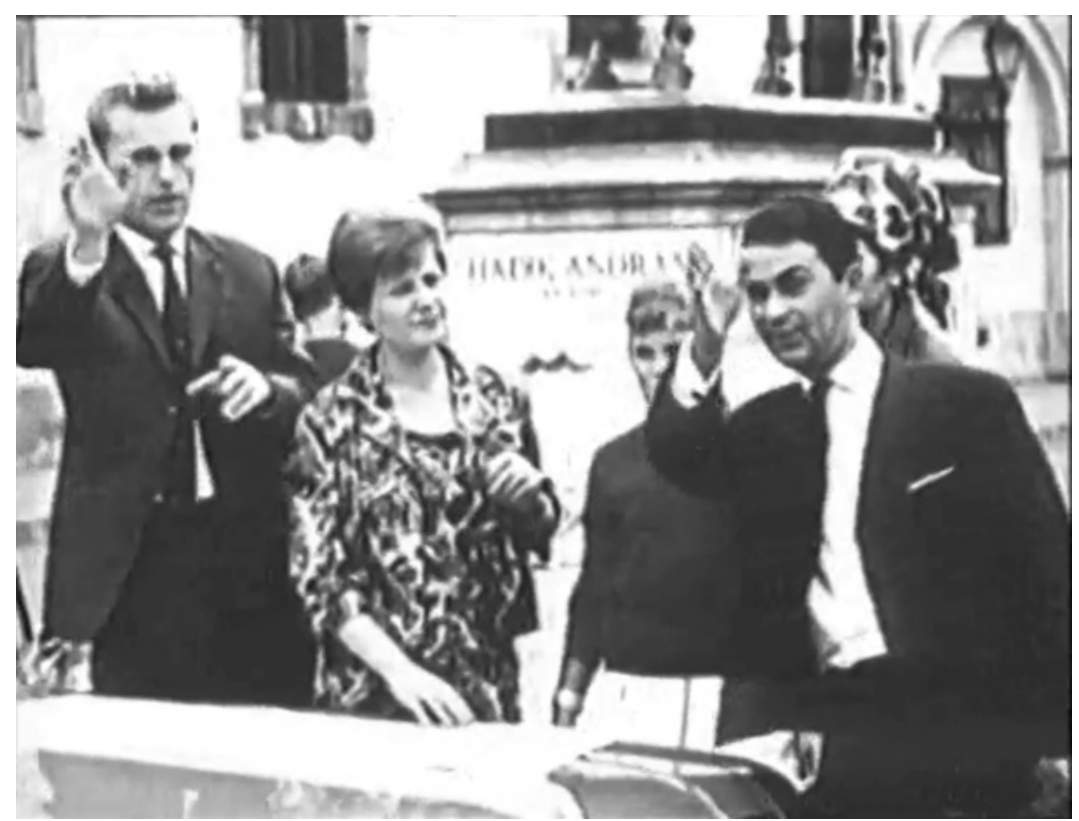

A vizsgált forrásokban, a közterek tekintetében kiemelt szerepe van a tisztaság (szemetelés) mellett a turizmusnak. Nem csak a belföldi és a más szocialista államokból érkező turisták kerülnek szóba: a rövid filmrészletekből az is kiderül, hogy a nyugati turisták látogatása különös büszkeséggel tölti el a müsorvezetőt, aki hangsúlyozza, hogy: „míg az '50-es években csak 30 ezer jól ellenőrzött külföldi jöhetett Budapestre, 1962-ben már 200 ezer valódi turista látogat a fővárosba, köztük sokan Nyugat-Európából" (Budapest Retro 1998, 1:50.).

A prioritásokat és a felújítások, befektetések szempontjából rangsorolt helyszíneket is meghatározta ez a szemlélet: Különös gondot kell fordítani azon közterületek tisztaságára és rendjére, melyeket nagy tömegek - bel- és külföldiek látogatnak. Nevezetesen: föterek, közlekedési csomópontok, protokoll-útvonalak, a városba be- és kivezető foútvonalak, sportlétesítmények környéke, zöld- és üdülőterületek stb. (Budapest Főváros Tanácsa tanácsülési jegyzőkönyve 1978, 5.).12

A beállított, szerkesztett jelentekből egyértelmüen kitünik az állam ,jelenléte” a felvételek során (1. és 2. ábra). Az összeállított interjúválaszokból és a sokszor nyilvánvalóan betanult mondatokból egyértelmüen kitűnik, hogy nem az „utca emberét” hallgatjuk. Ahogy Papp (2018 NMHH) fogalmaz egy interjúban „,[a]zt szoktam mondani, hogy ezek a dokumentumfilmek nem is a Kádár-korszakról, hanem a korszak propagandájáról szólnak, arról, hogy a politika milyennek akarta a rendszert bemutatni”. 
A direkt és az indirekt ideológiai alapú állami köztértermelés is meghatározó a közterek demokratikussága, hanyatlása szempontjából. A nemzetközi irodalomban leírt várositér-militarizációnak, köztérhanyatlásnak is az egyik meghatározó elemét jelentik azok az intézkedések, amelyek a rendteremtés segítségével helyeznek előtérbe privilegizáltabb csoportokat és az általuk látogatott tereket.

\section{A budapesti városi terek militarizációja és a közterek hanyatlása}

A hazai kritikai irodalomban a 2000-es évek végén, és leginkább 2012 után kezdtek megjelenni az első tanulmányok a köztér hanyatlásával, és a városi tér militarizációjával kapcsolatban (sokszor közvetve utalva ezekre a folyamatokra). Mind a budapesti kerületekben (Boros 2017; Ivanics 2013; Udvarhelyi 2010), mind a vidéki (nagy)városokban (Boros 2007, 2018; Vedrédi 2014) ekkor kezdtek felerősödni azok a neoliberális városvezetési stratégiák, amelyek a versenyképes (bel)város érdekében leplezetlenül kriminalizálják a szegénységet és elsősorban a hajléktalanságot. Azonban, ahogy a forrásokból is kiderül, nem húzható markáns vonal a rendszerváltozás előtti és azt követő tendenciák közé. Az előző fejezet alapján arra következtethetünk, hogy a turizmus és általában a „megtisztított” eladható város elképzelése nem állt távol a város köztérpolitikájától az államszocializmus idején sem. De a szegénységet stigmatizáló „közveszélyes munkakerülők" kategóriája vagy a tanácsi jegyzőkönyv erre utaló részei is azt sugallják, hogy a szegénység kriminalizálásának korábbi időszakokra visszanyúló, helyi hagyományai is vannak: „A program [ami Budapest rendjét és tisztaságát hivatott javítani] teljesítéséhez elengedhetetlenül szükséges, hogy a társadalmi szervek, a sajtó, a Rádió, Televízió, a budapesti és kerületi rendőrkapitányságok hathatós támogatást nyújtsanak: A Rendőrség a helyszíni ellenőrzéssel, a fokozott helyszíni bírságolással, a jogosulatlan utcai árusítás felszámolásával, a tilosban parkoló kocsik eltávolításával, az utcai kéregetők visszaszorításával”. (Budapest Főváros Tanácsa tanácsülési jegyzőkönyve 1978, 20.). ${ }^{13}$

Nagy Terézia (2009) írásában részletesebben olvashatunk a szocializmus rejtett hajléktalanságáról, és arról, hogy a szegénység egyszerre volt tabusítva, stigmatizálva és kriminalizálva, amiket az olyan állandó jelzők erősítettek fel, mint a „csöves”, „csavargó” vagy a „közveszélyes munkakerülő”.

Elmondható tehát a budapesti (késő) államszocialista közterek kapcsán, hogy már akkor megjelentek azok az elképzelések, melyek szerint a szegények nem egyszerűen a társadalom áldozatai vagy vesztesei, hanem - saját sorsuk kovácsaként - elkövetők. Tehát a szegénység bűncselekményként jelenik meg.

A szegénység ilyen típusú stigmatizálása mellett jelen voltak azok a rendszert sokkal jobban meghatározó ideológiai normák is, amelyek korlátozták, hogy a köztereken a megszokottól eltérő csoportok hirdessék identitásu- 
kat, legyen az például szexuális, vallási vagy politikai. Kosztolányi Gusztáv (1999) úgy ír a szocializmus kései időszakáról, hogy amíg valaki nem keveredett bele politikai kérdésekbe, addig viselhetett farmert és hordhatta hosszan a haját. A rendszerváltozással ez utóbbi jelentősen megváltozott és az utcákon jogilag engedélyezetté váltak például a felvonulások és a tüntetések, ugyanakkor a szegénység kirekesztése radikalizálódott. Ez tulajdonképpen le is írja azt a kettősséget, ami a (neo)liberalizmus/ piackapitalizmus és a demokrácia szimultán megjelenéséből fakadt.

\section{Konklúzió}

Írásom célja az volt, hogy a kritikai földrajz által meghatározott városmilitarizáció és az ezáltali köztérhanyatlás jelenségét - az állam szerepét kiemelve - történeti perspektívában vizsgáljam Magyarország és elsősorban Budapest kontextusában. A történetiséget azért találtam fontosnak, mert bár az angolszász irodalom által tárgyalt városmilitarizációs tendenciák jellemzik Budapest utcáit is, a köztér hanyatlásának elmélete azt feltételezi, hogy valaha (valahol) létezett köztér, ami korábban demokratikusabb volt.

Nem egyértelmű tehát a válasz, hogy beszélhetünk-e a demokratikus köztér hanyatlásáról, ha azon olyan folyamatot értünk, amit egy előzőleg demokratikus(abb) köztér felváltása jellemez. Phillips (2006) hasonló kérdést vet fel a centrumországokkal kapcsolatban. Véleménye szerint legfeljebb a demokratikus közterekért folytatott harcról és annak kiépítéséről beszélhetünk, és semmiképp sem azok újjáélesztéséről és visszaszerzéséről. Ez az elképzelés Budapest posztszocialista kontextusában talán még inkább elmondható.

A vizsgált szakirodalmakból és az archív dokumentumokból mindenestre az derül ki, hogy nem beszélhetünk egyértelmű tendenciáról (és egyértelmű határvonalakról sem). A rendszerváltozást követő időszakhoz, és a közelmúlthoz hasonlóan, az államszocializmus idején is kiemelt szerepet kapott a turisztikailag fontos területek esztétikája (és azoknak a nemzetközi piacon való értékesíthetősége), aminek része nemcsak a szegénység látszólagos eltüntetése, de az egyéni felelősségre vonás és a kriminalizálás is.

Mindezek alapján elmondható, hogy a Davis által leírt városmilitarizáció - amit a tőke és a piaci érdekeket kiszolgáló állam és a neoliberális városvezetés együttesen eredményez -, jelen van Budapesten is, és a 2000-es évektől egyre inkább jellemző. Azonban a történeti áttekintés azt mutatja, hogy Budapest esetében a köztér demokratikus jellege hiányának távolabbra visszanyúló helyi sajátossága is van, hiszen a gyökerei már az államszocializmusban is jelen voltak, olyan - a köztér használatát szűkítő és abban bizonyos csoportokat privilegizáló - politikák formájában, melyek hátterében az állam állt. 
Végezetül pedig fontos hangsúlyozni, hogy a cikk alapvetően a lefebvre-i trialektikának (Berki 2015; Lefebvre 1991) csak az egyik pillérével, az elgondolt térrel (conceived space) foglalkozott, és azon belül is a központi és a helyi állam elgondolt terével. Ahhoz, hogy a köztér hanyatlását komplexebben megértsük helyi kontextusban, szükséges a megélt tér (lived space) és az érzékelt tér (percieved space) vizsgálata is empirikus kutatáson keresztül.

\section{Jegyzetek}

1 Pl. közterületen való „életvitelszerü tartózkodás” tiltása: 2013. évi CXLIX. törvény, és a 2018-as módosítása.

2 Látványos példa erre a VIII. kerületben elhelyezett $230 \mathrm{db}$ térfigyelő kamera (http://jkf.hu/ doks/_08_kerulet_kamera_terkep_honlapra_1603_red_k.jpg).

Pl. Erzsébet tér (Sági 2016)

Közgyüjteményi portál: https://hungaricana.hu/

A keresés során a „köztér” és a „közterület” voltak a fő kulcsszavak, melyeknek a szövegkörnyezetét vizsgáltam.

http://www.kozterulet-felugyelet.hu

7 Palonen (2008) írását követve a „város-szövegben” elsősorban az utcanevekre és köztéri szobrokra utalok és nem a tágabb értelemben vett szimbolikus városi tájra.

8 A tisztasági mozgalom az 1950-es években indult a főváros rendjének és a tisztaságának növelése érdekében.

9 1952. október 17. - Budapest Főváros Tanácsa tanácsülési jegyzőkönyvei (HU BFL XXIII.101.a.1)31

10 1952. október 17. - Budapest Főváros Tanácsa tanácsülési jegyzőkönyvei (HU BFL XXIII.101.a.1)63

11 1978. február 24. - Budapest Főváros Tanácsa tanácsülési jegyzőkönyvei (HU BFL XXIII.101.a.1)11

12 1978. február 24. - Budapest Főváros Tanácsa tanácsülési jegyzőkönyvei (HU BFL XXIII.101.a.1)169

13 1978. február 1. - Budapest Főváros Tanácsa Végrehajtó Bizottsága üléseinek jegyzőkönyvei (HU BFL XXIII.102.a.1)94

\section{Köszönetnyilvánítás}

A cikk elkészülésében sokat segítettek az oslói nyári egyetemen, Don Mitchell által vezetett „Public Space” kurzus és Timár Judit kommentjei, javaslatai. Továbbá szeretném megköszönni a lektoroktól kapott építő kritikákat, amelyeket, ha nem is sikerült maradéktalanul beépíteni ebbe az írásba, a későbbi munkáimhoz (a köztérkutatás továbbgondolásához) inspiratív segítséget adtak.

\section{Irodalom}

Anderson, B. (1983): Imagined Communities. Verso, London

Atkinson, R. (2003): Domestication by Cappuccino or a Revenge on Urban Space? Control and Empowerment in the Management of Public Spaces. Urban Studies, 9., 1829-1843. https:// doi.org/10.1080/0042098032000106627

Bancroft, A. (2000): Closed spaces, restricted places: The resurgence of politics in the work of 
Zygmunt Bauman. Contemporary Politics, 3., 283-288. https://doi.org/10.1080/713658364

Bauman, Z. (1998): Work, consumerism and the new poor. Open University Press, London

Bauman, Z. (2000): Liquid modernity. Polity, Cambridge

Berki M. (2015): A térbeliség trialektikája. Tér és Társadalom, 2., 3-18. https://doi.org/10.17649/TET. 29.2.2658

Bodnár, J., Molnár, V. (2010): Reconfiguring public and private: Capital, state and new housing developments in Berlin and Budapest. Urban Studies, 2., 789-812. https://doi.org/ $10.1177 / 0042098009351188$

Boros, L. (2007): ...But some are less equal - spatial exclusion in Szeged. In: Kovács Cs. (szerk.): From villages to cyberspace - Falvaktól a kibertérig. SZTE Gazdaság- és Társadalomföldrajz Tanszék, Szeged, 151-160.

Boros L. (2017): A közterek átalakulása és a turizmus. In: Régi T., Rátz T., Michalkó G. (szerk.): Turizmus és transzformáció. Kodolányi János Főiskola, MTA CSFK Földrajztudományi Intézet, Magyar Földrajzi Társaság, Orosháza, Budapest 131-149.

Boros L. (2018): A közterek áruvá válása a magyar városokban. Településföldrajzi tanulmányok, 1., 18-37.

Czirfusz M., Jelinek Cs., Berki M. (2018): Marxista nézetek a térről és térbeliségről. In: Faragó L. (szerk.): Kortárs térelméletek közép-kelet- európai kontextusban. Dialóg Campus Kiadó, Budapest, 143-164.

Davis, M. (1992 / 1999-2000): Los Angeles, az erődváros. A városi tér militarizációja. Budapesti Negyed, 26-27., 27-50.

Davis, M. (1998 / 2006): Fortress L.A. In: City of Quartz: Excavating the future in Los Angeles. Verso, London, 221-264.

Erőss Á. (2018): Szimbolikus terek és térhasználat többnemzetiségü városokban: Beregszász és Nagyvárad példája. PhD-értekezés. ELTE, Földtudományi Doktori Iskola, Budapest

Foucault, M. (1975 / 1991): Discipline and punish: The birth of the prison. Penguin Books, London

Gal, S. (2002): A semiotics of the public/private distinction. Differences. A Journal of Feminist Cultural Studies, 1., 77-95.

Gyáni G. (2007): A városi mikroterek társadalomtörténete. In: A. Gergely A., Bali J. (szerk.): Városantropológiai vázlatok és változatok: A város-megismerés kérdőjeleiből. MTA PTI Etnoregionális Kutatóközpont, ELTE BTK Néprajzi Intézet, Budapest, 266-276.

Habermas, J. (1962 / 1991): The structural transformation of the public sphere. MIT Press, Cambridge

Harvey, D. (2012): From the right to the city to the urban revolution. Verso, London

Hubbard, P. (2001): Sex zones: Intimacy, citizenship and public space. Sexualities, 4., 51-71. https:// doi.org/10.1177/136346001004001003

Ivanics Zs. (2013): Bevezetés: Város és biztonság. In: Jelinek Cs., Bodnár J., Czirfusz M., Gyimesi Z. (szerk.): Kritikai városkutatás. L'Harmattan Kiadó, Budapest, 335-344.

Iveson, K. (2007): Publics and the city. Wiley, London

Kosztolányi, G. (1999): Consumerism: Shop till You Drop. Central Europe Review, 16 August, 8.

Lefebvre, H. (1967 / 1996): Writings on cities. Wiley, London

Lefebvre, H. (1974/1991): The production of space. Blackwell, Oxford

Madden, D. J. (2010): Revisiting the end of public space: Assembling the public in an urban park. City \& Community, 2., 187-205. https://doi.org/10111/j.1540-6040.2010.01321.x

McDowell, L. (1983): Towards an understanding of the gender division of urban space. Environment Planning D: Society and Space, 1., 59-73. https://doi.org/10.1068/d010059

Misetics B. (2010): Otthontalan, csupa-csősz világ. Replika, 2., 29-44.

Misetics, B. (2017): Homelessness, citizenship and need interpretation: reflections on organizing with homeless people in Hungary. Interface: A journal for and about social movements, 1., $389-423$.

Mitchell, D. (2003): The Right to The City: Social Justice and the Fight for the City. Guilford Press, Guilford

Nagy T. (2009): Átmenet a szocializmus rejtett hajléktalan világából a kvázi jóléti szociális vetőhálóba. Tér és Társadalom, 3., 79-96. https://doi.org/10.17649/TET.23.3.1258

NMHH (2018): Szabó Magda mondatai évtizedekre beleragadnak az emberbe - Interjú Papp Gábor Zsigmond rendezővel https://mediatanacs.blog.hu/2018/08/28/szabo_magda_mondatai_evtizedekre_be- 
leragadnak_az_emberbe_interju_papp_gabor_zsigmond_rendezovel (Letöltés: 2019. szept. 14.)

Palonen, E. (2008): The city-text in post-communist Budapest: street names, memorials and the politics of commemoration. GeoJournal, 3., 219-230. https://doi.org/10.1007/s10708-008-92042

Phillips, D. (2006): Parallel lives? Challenging discourses of British Muslim self-segregation. Environment and Planning D: Society and Space, 1., 25-40. https://doi.org/10.1068/d60j

Reszler G. (2014): A totalitárius rendszerek és a társadalmi tér választóvonalai. In: Buhály A., Reszler G., Szoboszlay G. (szerk.): Falak és választóvonalak a történelemben. Nyíregyházi Főiskola Történettudományi és Filozófia Intézete, Nyíregyháza, 131-240.

Saegart, S. (1981): Masculine Cities and Feminine Suburbs: Polarised Ideas, Contradictory Realities. In: Stimpson, C. R., Dixler, E., Nelson, M. J., Yatrakis, K. B. (eds.): Women in the American city. University of Chicago, Chicago, S96-S111.

Sági, M. (2016): Public space 'development' in the city centre of Budapest. In: Árpási Z., Bodnár G., Gurzó I. (szerk.): A magyar gazdaság és társadalom a 21. század globalizálódó világában 1. kötet. Szent István University, Békéscsaba, 80-86.

Sági M. (2018): Test és tér: Patriarchális viszonyok újratermelése városi köztereken. In: Faragó L. (szerk.): Kortárs térelméletek kelet-közép-európai kontextusban. Dialóg Campus Kiadó, Budapest, 205-218.

Timár J. (1993): A nők tanulmányozása a földrajzban, avagy: van-e létjogosultsága a feminista geográfiának Magyarországon? Tér és Társadalom, 1-2., 1-18. https://doi.org/10.17649/ TET.7.1-2.267

Timár J. (2018): A feminista és a marxista földrajz kapcsolata: összekötő és elválasztó diskurzusok a térről. In: Faragó L. (szerk.): Kortárs térelméletek közép-kelet-európai kontextusban. Dialóg Campus Kiadó, Budapest, 187-203.

Timár J., Nagy E. (2019): Állam és tértermelés: „új” értelmezési keretek a tértudományokban. Tér és Társadalom, 4., 3-16. https://doi.org/10.17649/TET.33.4.3214

Tyshchenko, I. (2017): A Return to public space. https://www.academia.edu/20319192/Challenges_of_Public_Space

Udvarhelyi, T. É. (2010): Man on the street. Anthropology, citizenship and the fight for housing rights in Hungary. Practicing Anthropology, 2., 17-20.

Udvarhelyi, T. É. (2014): "If we don't push homeless people out, we will end up being pushed out by them": The criminalization of homelessness as state strategy in Hungary. Antipode, 3., 816-834. https://doi.org/10.1111/anti.12068

Udvarhelyi, T. É. (2019): Building a movement for the right to housing in Hungary. Urban Research \& Practice, 2., 192-200. https://doi.org/10.1080/17535069.2018.1532714

Vedrédi, K. (2014): Social perception of public space developments - The case of Saint Stephen square, Szeged, Hungary. European Journal of Geography, 3., 60 -72.

Wilson, E. (1995): The rhetoric of urban space. New Left Review, 209., 146-160.

\section{Felhasznált források}

Papp Gábor Zsigmond (1998): Budapest Retro

1952. október 17. - Budapest Főváros Tanácsa tanácsülési jegyzőkönyvei (HU BFL XXIII.101.a.1)

1978. február 24. - Budapest Főváros Tanácsa tanácsülési jegyzőkönyvei (HU BFL XXIII.101.a.1) 